\title{
Different soil structure and water conditions affect the growing response of Lolium perenne L. and Bromus valdivianus Phil. growing alone or in mixture
}

\author{
Constanza Descalzi ${ }^{1,4}$ Oscar Balocchi ${ }^{2}$, Ignacio López ${ }^{3,4}$, Peter Kemp ${ }^{3,4}$, José Dörner ${ }^{4,5 *}$
}

${ }^{1}$ Graduate School, Faculty of Agricultural Science, Universidad Austral de Chile, Valdivia, Chile.

${ }^{2}$ Instituto de Producción Animal, Facultad de Ciencias Agrarias, Universidad Austral de Chile, Valdivia, Chile. ${ }_{3}^{3}$ Institute of Agriculture and Environment, Massey University, Palmerston North, New Zealand. ${ }^{4}$ Centro de Investigación en Suelos Volcánicos, Universidad Austral de Chile, Valdivia, Chile.

${ }_{5}^{5}$ Instituto de Ingeniería Agraria y Suelos, Facultad de Ciencias Agrarias, Universidad Austral de Chile, Valdivia, Chile.*Correspondence author: cdescalzil@gmail.com; josedorner@uach.cl

\begin{abstract}
Restricting plant available water in the soil can negatively affect pasture growth. Lolium perenne L. (Lp) and Bromus valdivianus Phil. (Bv) are important components of the permanent pastures in southern Chile. The aim of this study was to investigate the growth response of $\mathrm{Lp}$ and $\mathrm{Bv}$ when subjected to soil water restriction, contrasting soil structure conditions and growing as a single species pasture or in a mixture. The treatments were two soil physical conditions (undisturbed (US) and disturbed soil (DS)), two soil water restriction levels (optimum PAW and very-dry PAW), and three pastures (Bv, Lp and $\mathrm{Bv}+\mathrm{Lp}$ ). The US provided more water to plants regardless of the soil water restriction, and Bv and Lp presented more development (highest accumulated herbage mass) in US than in DS, under a similar soil water restriction. The soil structure and soil water restriction did not modify the tiller number of Bv, although Lp showed different tiller numbers under each condition, soil structure and soil water restriction. The conservation of the soil structure (undisturbed soil) has an important role in pasture productivity by providing a continuous pore system, which certainly improved the water accessibility for the growing species.
\end{abstract}

Keywords: Shoot and root production, relative competitive index, tiller number, soil air capacity, plant available water and pore continuity 


\section{Introduction}

In livestock production, grasslands are one of the main sources of feed, as they provide much of the fodder required for animals. In southern Chile, animals graze the pasture throughout the year (Balocchi and Teuber, 2003). Therefore, pastures are relevant for livestock production since they constitute a low cost source of food (Teuber et al., 2007). This part of the country is dominated by volcanic ash soils and has a temperate humid climate that allows permanent pastures to grow and to develop grazing systems. In recent years a decrease in rainfall and an increase in temperatures have been observed (Boisier et al., 2016), with soil water tensions being near to the permanent wilting point at $60 \mathrm{~cm}$ depth in March of 2015 (Ordóñez et al., 2018). These changes in climatic conditions increase the risk of soil water restriction for pasture species and may compromise their survival after successive summer droughts (Volaire et al., 2009).

In the south of Chile Lolium perenne L. (Lp) and Bromus valdivianus Phil. (Bv) are desirable species in the pasture because of their high productive potential (12000 kg dry matter (DM) ha-1 year $^{-1}$ ) and good forage quality (levels of crude protein $16-20 \%$ and metabolizable energy 2.3 - 3.0 Mcal) (Balocchi and Teuber., 2003). Both species, being of similar nutritional and edaphic requirements, tend to colonize high fertility soils (Balocchi et al., 2001). However, they have different mechanisms of tolerance to soil water restriction. While Lp enters summer dormancy, due to soil water restriction (Silsbury., 1961), Bv has a higher soil water restriction toleration (Balocchi et al., 2001, López et al., 2013). Under soil water restriction, Bv increases its dominance in the pasture while Lp diminishes its presence (Descalzi et al., 2011). Bromus valdivianus has shown a more stable tiller dynamic throughout the year than Lp (Descalzi et al., 2011). Both species have differences in the soil depth that their root systems explore. While the roots of $\mathrm{Lp}$ are no larger than $1.0 \mathrm{~m}$ deep, the roots of $\mathrm{Bv}$ reach $1.5 \mathrm{~m}$ in depth (Stewart, 1996, Nie et al., 2008). The latter is relevant since deeper root systems can reach water from deeper soil horizons (Singh et al., 2003).

Volcanic ash soils in southern Chile are characterized by presenting a large volume of pores at different water tensions, as well as very high saturated and unsaturated hydraulic conductivity due to the presence of a well-defined structure- and texture-dependent porosity (Dörner et al., 2015). Under ideal levels of water content in soil (e.g. near to field capacity which means for a volcanic ash soil, a volumetric water content of approximately $50-55 \%$ which corresponds to at least $20 \%$ of plant available water according to Dörner et al., (2013)) the plant water accessibility depends on the root distribution and density, and the capacity of the soil to provide water to the roots at a certain rate (Droogers et al., 1997). Water accessibility is determined by the distribution of soil aggregates which define the continuity and interconnectivity of the pore system (Dörner and Dec., 2007). In structured soils, the porous system is continuous and interconnected, which is essential for drainage, aeration and root growth (Dörner and Dec., 2007). However, when soil structure is modified by soil tillage the pore system is broken and, therefore, the accessibility of water due to changes in pore continuity is negatively affected (Zúñiga et al., 2015). These contrasting conditions of soil pore systems may affect the response of species with different root systems to water stress, especially under rain fed management. Therefore, questions related to the ability of plants to access water under different soil structure conditions and water stress become relevant. In these terms, the aim of this work was to compare the growth response of Lolium perenne L. (Lp) and Bromus valdivianus Phil. (Bv) under soil water restriction and contrasting soil structure conditions. 


\section{Materials and Methods}

\subsection{Plant establishment}

A greenhouse study was established in the Faculty of Agricultural Science, Universidad Austral de Chile, Valdivia $\left(39^{\circ} 45^{\prime} 30^{\prime \prime}\right.$ latitude south and $73^{\circ} 14^{\prime} 55^{\prime \prime}$ longitude west), from May 2014 to May 2015. A volcanic ash soil from the Valdivia Series (Duric Hapludand) that comprised two different soil structure conditions, disturbed soil (sieved and homogeneously mixed soil; DS) and undisturbed soil (structured soil; US) was used. The soil series presents a silty loam soil texture, organic matter content between 9.9\% (in degraded pastures) and $15.5 \%$ (under floodplain native forest) in the first five $\mathrm{cm}$. Depending on soil management, the soil bulk densities ranged between 0.6 and $0.7 \mathrm{~g} \mathrm{~cm}^{-3}, \mathrm{pH}_{\text {(water) }}$ of 5.6 with levels of extractable aluminum close to $1200 \mathrm{mg} \mathrm{kg}^{-1}$. More information about the soil series can be found in Dörner et al., (2013), Dörner et al. (2015) and Zúñiga et al., (2015). Soil samples were collected from the first 20 $\mathrm{cm}$ of soil depth in order to be analyzed for chemical properties. The soil chemical properties were as follows: $17 \%$ soil organic matter (SOM), $15.4 \mathrm{mg} \mathrm{kg}^{-1}$ mineral-N $\left(\mathrm{N}^{-N^{3+}} \mathrm{NH}_{4}\right), 3.4 \mathrm{mg} \mathrm{kg}^{-1}$ Olsen-P, $84 \mathrm{mg}$ $\mathrm{kg}^{-1}$ exchangeable $\mathrm{K}^{+}, 0.14 \mathrm{cmol}^{+} \mathrm{kg}^{-1}$ exchangeable $\mathrm{Na}^{+}, 1.74 \mathrm{cmol}^{+} \mathrm{kg}^{-1}$ exchangeable $\mathrm{Ca}^{2+}, 0.95 \mathrm{cmol}^{+}$ $\mathrm{kg}^{-1}$ exchangeable $\mathrm{Mg}^{2+}, 3.04 \mathrm{cmol}^{+} \mathrm{kg}^{-1}$ soil total exchangeable bases (STEB), $3.16 \mathrm{cmol}^{+} \mathrm{kg}^{-1}$ exchangeable $\mathrm{Al}^{3+}, 6.2 \mathrm{cmol}^{+} \mathrm{kg}^{-1}$ cations exchangeable capacity (CEC) and $13.2 \%$ aluminum saturation.

Plastic pots (cylindrical PVC tubes) of $25 \mathrm{~cm}$ diameter and $50 \mathrm{~cm}$ height in which one end was sharpened, were used for the study. The US pots were placed on the ground with the sharpened end facing the soil and perpendicularly inserted into the soil by using a backhoe loader. At this time the soil water content was near to field capacity, thus the PVC tubes were easily inserted into the soil, without major soil structure deformation due to a high shear resistance. To prevent the soil falling out from the bottom end of the pots, a mesh was secured. Subsequently, the pots were transported to the greenhouse.

Soil from the same site was dug out $(0-20 \mathrm{~cm}$ depth), collected and transported to the greenhouse. We decided to use the soil from the first $20 \mathrm{~cm}$, since no major differences in soil texture were identified up to $50 \mathrm{~cm}$ depth (Zúñiga et al., 2015). At the greenhouse, the soil was sieved through a $1 \mathrm{~cm}^{2}$ mesh and used to fill up the DS pots. Soil moisture was measured and the gravimetric water content calculated and used to determine the amount of soil required to obtain a bulk density of $0.7 \mathrm{~g} \mathrm{~cm}^{-3}$. The bulk density was previously defined by collecting undisturbed soil samples $\left(230 \mathrm{~cm}^{3}\right)$ in the same site following the methodology given by Hartge and Horn (2009). To prevent the soil falling out of the bottom end of the DS pots, a mesh was secured to prevent soil losses.

The results of the soil chemical analysis were used to determine the following equivalent soil fertilization: $2000 \mathrm{~kg} \mathrm{ha}^{-1}$ of lime, $664 \mathrm{~kg} \mathrm{P} \mathrm{ha}^{-1}, 62 \mathrm{~kg} \mathrm{~K} \mathrm{ha}^{-1}$ and $100 \mathrm{~kg} \mathrm{~N} \mathrm{ha}^{-1}$ were applied on the soil surface before seeding.

\subsection{Experiment establishment}

The experiment had 27 pots for US and 27 pots for DS. Three types of pasture were established in both, US and DS. One monoculture pasture was sown with 16 seeds of Bv per pot, seeds that were harvested during summer, 2014, from naturalized Bv plants in southern Chile. Another monoculture pasture was sown with 16 seeds of Lp cv. Rohan per pot. The third pasture was sown with a mixed pasture of $\mathrm{Bv}$ and $\mathrm{Lp}$ ( 8 seeds of each species per pot). Eight equidistant positions located at five $\mathrm{cm}$ from the edge of the pot were determined in each pot. Two seeds were 
placed into each position. The seeds were covered with a thin layer of soil. Five days after plantlet emergence, only one plantlet was left in each individual position in the pots.

After plant emergence all pots were kept at field capacity (volumetric water content at $60 \mathrm{hPa}$ of water tension according to Hartge and Horn., (2009), as normally used for volcanic soils in southern Chile), which means, according to the measured water retention curve (explained below), at soil volumetric water content of $53.0 \%$ for US and $51.5 \%$ for DS. Plants were grown under these conditions until the tillers of the first species presented the first dead leaf ( 75 days in the greenhouse after emergence). At this point the shoots were cut leaving all the plants in the pots at a five $\mathrm{cm}$ plant height, and the two soil water restriction treatments of the plant available water (PAW) were imposed: "optimum PAW" (80-85\% of PAW) and very-dry PAW (20-25\% of PAW).

To accomplish the different soil water restriction levels of PAW, a water retention curve ( $\mathrm{pF}$ curve) was measured according to Dörner et al., (2015) and Hartge and Horn., (2009). Six soil samples collected between 0-10 and 25-35 soil depth from each US and DS were analyzed. The PAW (\% vol) was defined, as follows (Equation 1), using the volumetric water contents $(\theta)$ at 60 and 15430 of water tension (Dörner et al., 2015):

$P A W=\theta_{60 \mathrm{hPa}}-\theta_{15430 \mathrm{hPa}} \quad$ Equation 1

The PAW reached $28 \%$ for US and $26 \%$ for DS. The volumetric soil water content at the permanent wilting point (PWP) was $25 \%$ for both DS and US. These data facilitated the calculation of the required amount of water to add to the pots to get the different soil water restriction levels. Soil water content (vol.\%) was monitored daily at 10 and $35 \mathrm{~cm}$ soil depth, at 9:00 am and 5:00 pm, utilizing 5TM sensors (Decagon Devices, Pullman, Wa, USA) that were installed in extra replicates of pots (Figure 1). The sensors were previously calibrated as done by Dörner et al., (2010). The optimum PAW and verydry PAW treatments had $45 \%$ and $30 \%$ of soil water content, respectively, which was valid for US and DS (Figure 1). 


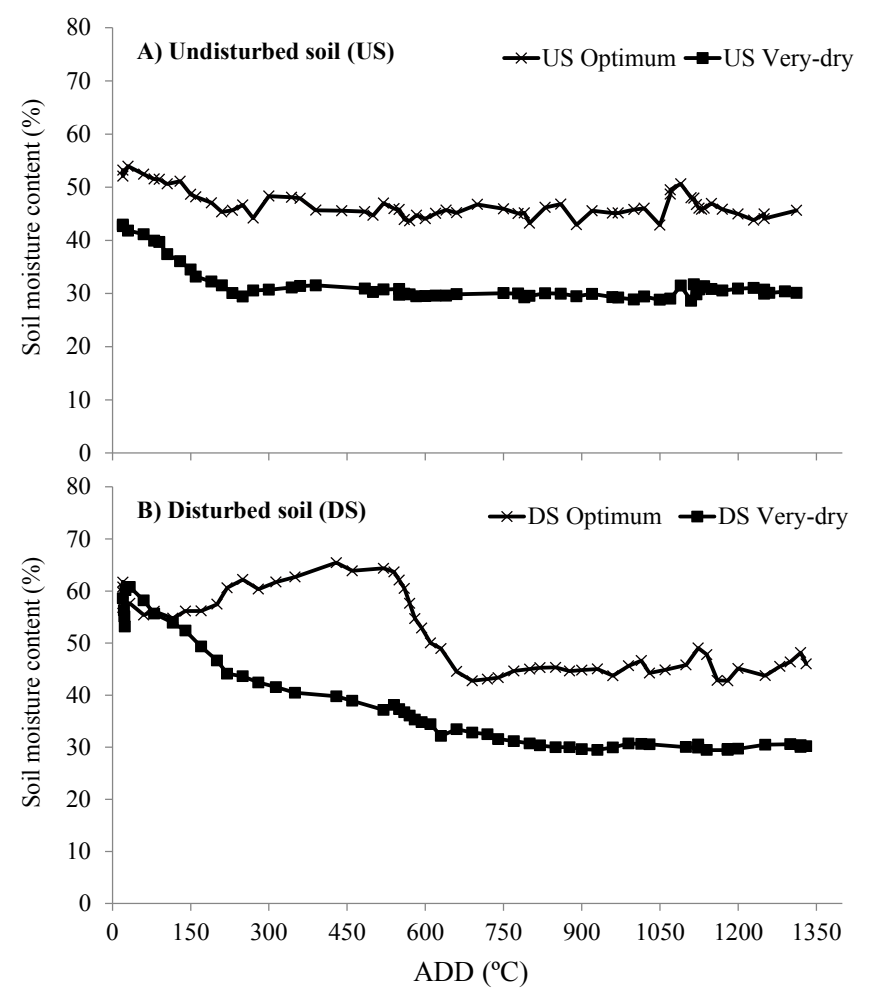

Figure 1. Changes in soil water content (\%) as a function of accumulated degree day (ADD) considering: A) Undisturbed soil (US) under optimum PAW and very-dry PAW; B) Disturbed soil (DS) under optimum PAW and very-dry PAW. The values correspond to the mean values between 10 and $35 \mathrm{~cm}$ depth.

The total time that the plants were subjected to the different water treatments was 1196 accumulated degree day (ADD) with $5{ }^{\circ} \mathrm{C}$ as base temperature (corresponding to 60 days in the greenhouse), being equivalent to the ADD of a summer water restriction period in southern Chile (López et al., 2013).

\subsection{Evaluations}

Two homogeneous tillers per pot of each species were marked, and the leaf length (ligule to the tip) was measured. The leaf elongation and leaf senescence $\left(\mathrm{mm}\right.$ day $^{-1}$ of leaf chlorotic tissue) was calculated
(Hodgson et al., 1981). In addition, leaf number per tiller was counted every three days on the marked tillers during the whole period of water restriction. At the end of the experiment (1196 ADD) a destructive harvest was performed to determine the total tiller number per pot and per species, in US and DS and under each soil water restriction treatment. In all cases two tillers per species were cut at the base to determine their water potential at 5:00 am (before sunrise when the stomata were closed) and at 12:30 pm (at midday when all the stomata were open) utilizing a Scholander pump (model 1000 pressure chamber). In each pot the plant shoots were cut at ground level and 
separated from the roots. The roots were harvested at $0-10,10-20,20-35,35-50 \mathrm{~cm}$ soil depth and then washed. After that, shoots and roots were dried out at $60{ }^{\circ} \mathrm{C}$ for $48 \mathrm{~h}$ and the dry weight recorded (Hodgson et al., 1981).

The relative competitive index (RCI) when Lp and Bv grew together was calculated using Grace's equation (Equation. 2) (Grace, 1995):

$$
R C I=\left(S D M-\frac{S M D M}{S D M}\right) \quad \text { Equation } 2
$$

Where SDM corresponded to the species growing as a single species pasture and SMDM corresponded to the species growing as a mixed pasture, respectively. The data of tiller number and shoot dry matter of both species was used to calculate RCI.

In order to determine soil physical properties in US and DS after the experiment, the water retention curve ( $\mathrm{pF}$ curve) and the air permeability were measured from the undisturbed soil samples collected with metallic cylinders $\left(230 \mathrm{~cm}^{3}, \mathrm{n}=6\right.$ for each soil conditions, water treatment and depth) at $0-10$ and $25-35 \mathrm{~cm}$ soil depth. From these samples the bulk density, air capacity and plant available water were determined. The air permeability and two pore-continuity indexes $\left(\mathrm{C}_{2}\right.$ and $\mathrm{C}_{3}$ ) were defined at water tensions of 60 and $330 \mathrm{hPa}$. All these analyses were performed following Dörner et al. (2015) and Zúñiga et al. (2015).

\subsection{Experimental design and statistical analysis}

A complete randomized block design $(n=3)$ with a $2 \times 2 \times 3$ factorial arrangement (two soil structures (DS and US) $\mathrm{x}$ two soil water restriction levels (optimum PAW and very-dry PAW) $x$ three types of pasture (single species pasture of Bromus valdivianus and Lolium perenne; and the $50 \% \mathrm{Bv}$ and $50 \% \mathrm{Lp}$ mixed pasture) was used. The data was first subjected to analysis of normality and homogeneity of variance, and then an analysis of variance was performed using the general linear model procedure (PROC GLM) of SAS version 9.1.3 (Statistical Analysis System, SAS Institute, Cary, NC. 2011). The least significant difference (LSD) test was used to separate the means. Significant statistical interaction between the main classes was analyzed by the probability of differences (PDIFF) test and the treatment means were separated. Significant differences were declared at $\mathrm{P} \leq 0.05$.

\section{Results}

\subsection{Plant growth under different soil physical condi- tions and water managements}

Accumulated leaf elongation of $\mathrm{Bv}$ and $\mathrm{Lp}$ submitted to different soil water restrictions in DS and US are presented in Figure 2. The soil structure had a strong effect on leaf elongation of both species. Bromus valdivianus in US had 4 times greater accumulated leaf length $(1600 \mathrm{~mm})$ than in DS $(400 \mathrm{~mm})$. Lolium perenne in US had 2 times greater accumulated leaf length $(750 \mathrm{~mm})$ than $\mathrm{Lp}$ in DS. Under optimum PAW, and very-dry PAW, it was observed that Bromus valdivianus did not differ in the accumulated leaf elongation when grown as "monoculture" or as mixed pasture with Lp under DS and US, or under each soil water restriction treatment. On the other hand, Lp did not differ in the accumulated leaf elongation between soil water restriction treatments in US or DS.

A three way interaction between soil structure $\mathrm{x}$ soil water restriction $\mathrm{x}$ pastures for the leaf elongation and leaf senescence rate was observed (Table 1). For both species, leaf elongation and senescence diminished under the very-dry PAW, compared to the optimum PAW. However, Bv grown in US and DS, as monoculture or in mixture with $\mathrm{Lp}$, presented higher leaf elongation rate $(P \leq 0.001)$ and greater leaf senescence rate $(\mathrm{P} \leq 0.001)$ than Lp (Table 1$)$. 

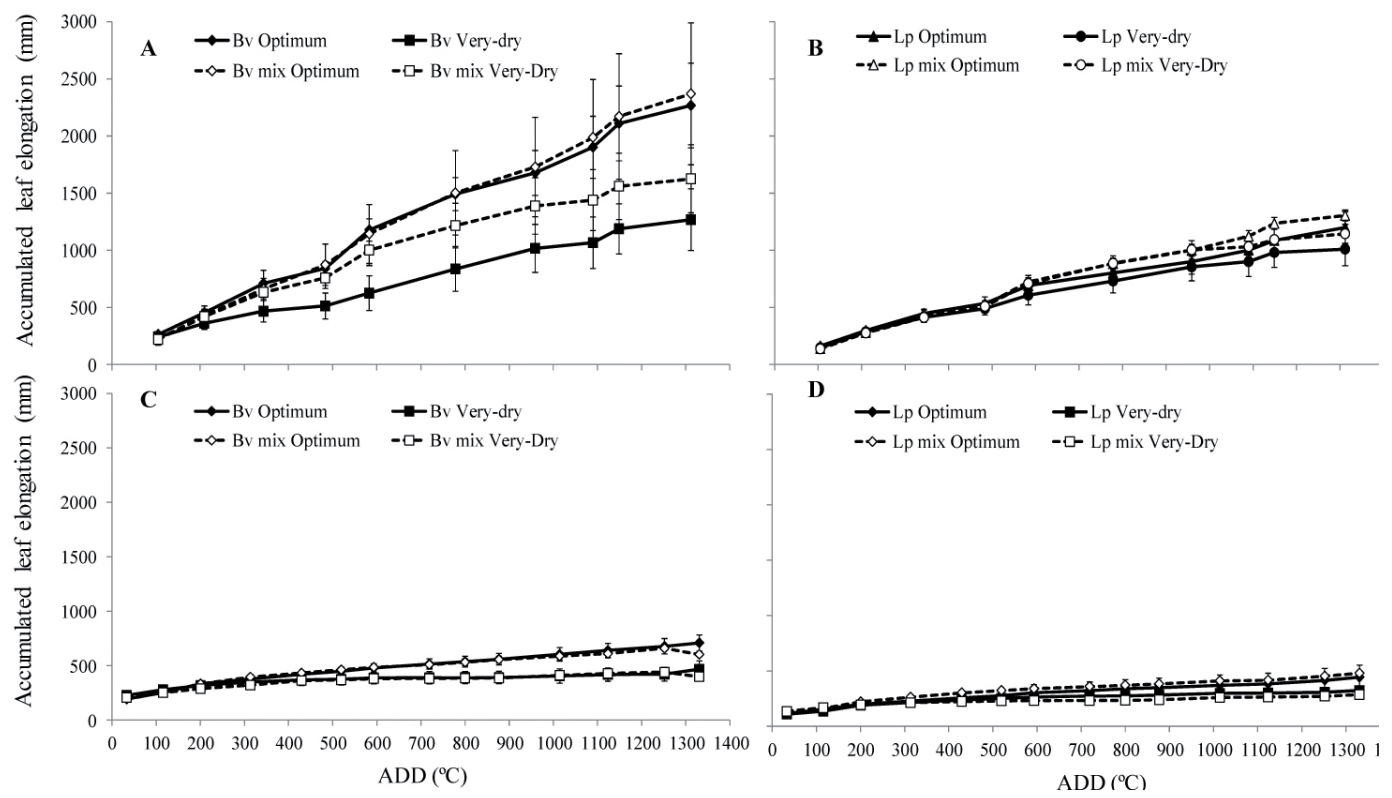

Figure 2. Accumulated leaf elongation ( $\mathrm{mm}$ ) of Bromus valdivianus and Lolium perenne in monoculture and mixed pasture under two soil water restrictions (optimum PAW and very-dry PAW). A) Bromus valdivianus (Bv) in undisturbed soil (US); B) Lolium perenne (Lp) in US; C) Bromus valdivianus (Bv) in disturbed soil (DS); D) Lolium perenne (Lp) in DS. In the period 1196 accumulated degree day (ADD). Average values are presented and vertical bars indicate standard error of the mean $(n=3)$.

Thus, the leaf elongation of $\mathrm{Bv}$ in the optimum PAW was 1.7 and 1.9 times larger than $\mathrm{Lp}$ when grown in DS and US, respectively $(\mathrm{P} \leq 0.001)$.

When water was not restricted (optimum PAW) to $\mathrm{Bv}$ and $\mathrm{Lp}$ growing as monoculture and as mixed pasture, there was a significantly greater leaf elongation $(\mathrm{P} \leq$ 0.001 ) in US than in DS (3.4 times greater for Bv and 2.9 times greater for Lp). Under very-dry PAW, leaf elongation rate for $\mathrm{Bv}$ was 4.1 greater in US compared to that in DS, and for Lp it was 4.9 times higher in US in contrast to that in DS ( $\mathrm{P} \leq 0.001$; Table 1$)$. A statistical interaction between soil structure $\mathrm{x}$ soil water restriction $\mathrm{x}$ pastures $(\mathrm{P} \leq 0.001$; Table 1$)$ for plant tiller number was evaluated at the end of the experimental period. The soil structure and soil waterrestriction did not alter $\mathrm{Bv}$ tiller number $(\mathrm{P}>0.05)$, reaching an average of 15 tillers per plant, when grown in monoculture or mixed with Lp. In the case of $\mathrm{Lp}$, an interaction was observed between soil structure $\mathrm{x}$ soil water restriction $\mathrm{x}$ pasture $(\mathrm{P} \leq 0.05)$. Thus, Lp monoculture under the US $x$ optimum PAW $x$ Lp had 1.2 times more tiller number per plant than the US $x$ very-dry PAW x Lp, and 1.9 times more tillernumber per plant than the DS $x$ optimum PAW $x \operatorname{Lp}(\mathrm{P} \leq 0.05)$. Under the US $x$ optimum PAW $x$ Lp monoculture there was a 1.5 times increase in tiller number per plant than in US $x$ optimum PAW x Lp mixed. The shoot mass per plant showed a three-way interaction. Lp had a higher shoot mass than $\mathrm{Bv}(\mathrm{P} \leq$ $0.05)$, and in the US there was a greater shoot mass than in the DS $(\mathrm{P} \leq 0.05)$. 
Table 1. Effect of two water treatments (optimum and very-dry) and three sward (Bromus valdivianus (Bv), Lolium perenne (Lp) and mixed $\mathrm{Lp}+\mathrm{Bv}$ ) under a disturbed (DS) and undisturbed (US) soil condition, in the growth (leaf elongation and senescence) and production (tiller number, shoot).

\begin{tabular}{|c|c|c|c|c|c|c|}
\hline & & & $\begin{array}{l}\text { Leaf elongation } \\
\left(\mathrm{mm} \mathrm{day}^{-1}\right)\end{array}$ & $\begin{array}{l}\text { Leaf senescence } \\
\left(\mathrm{mm} \text { day }^{-1}\right)\end{array}$ & $\begin{array}{l}\text { Tiller number } \\
\text { per plant }\end{array}$ & $\begin{array}{l}\text { Shoots } \\
\left(\mathrm{g} \mathrm{DM} \mathrm{plant}^{-1}\right)\end{array}$ \\
\hline Soil structure * & Soil water restriction $*$ & Pastures & & & & \\
\hline \multirow[t]{8}{*}{ Disturbed } & \multirow[t]{4}{*}{ Optimum PAW } & $\mathrm{Bv}$ & $11.65 \pm 1.91 \mathrm{e}$ & $5.12 \pm 0.97 \mathrm{e}$ & $13 \pm 0.37 \mathrm{c}$ & $2.59 \pm 0.17 \mathrm{e}$ \\
\hline & & $\mathrm{Lp}$ & $6.70 \pm 1.96 \mathrm{f}$ & $3.87 \pm 0.89 \mathrm{f}$ & $38 \pm 0.87 \mathrm{~b}$ & $3.03 \pm 0.16 \mathrm{~d}$ \\
\hline & & Bv mix & $10.90 \pm 1.53 \mathrm{e}$ & $3.42 \pm 1.37 \mathrm{f}$ & $8 \pm 0.60 \mathrm{c}$ & $1.57 \pm 0.01 \mathrm{f}$ \\
\hline & & Lp mix & $7.46 \pm 0.59 \mathrm{f}$ & $3.73 \pm 0.36 \mathrm{f}$ & $47 \pm 1.63 \mathrm{~b}$ & $4.05 \pm 0.16 \mathrm{c}$ \\
\hline & \multirow[t]{4}{*}{ Very-dry PAW } & $\mathrm{Bv}$ & $4.94 \pm 0.97 \mathrm{~g}$ & $3.46 \pm 0.32 \mathrm{f}$ & $17 \pm 0.71 \mathrm{c}$ & $3.19 \pm 0.62 \mathrm{~d}$ \\
\hline & & Lp & $4.37 \pm 0.74 \mathrm{~g}$ & $2.02 \pm 0.18 \mathrm{~g}$ & $45 \pm 2.13 \mathrm{~b}$ & $3.17 \pm 0.34 \mathrm{~d}$ \\
\hline & & Bv mix & $6.18 \pm 0.39 \mathrm{f}$ & $2.68 \pm 0.64 \mathrm{~g}$ & $15 \pm 2.42 \mathrm{c}$ & $2.62 \pm 0.69 \mathrm{e}$ \\
\hline & & Lp mix & $3.09 \pm 0.51 \mathrm{~g}$ & $1.17 \pm 0.64 \mathrm{~g}$ & $44 \pm 4.33 \mathrm{~b}$ & $3.45 \pm 0.42 \mathrm{~d}$ \\
\hline \multirow[t]{9}{*}{ Undisturbed } & \multirow[t]{4}{*}{ Optimum PAW } & $\mathrm{Bv}$ & $37.12 \pm 6.76 \mathrm{a}$ & $16.21 \pm 1.92 \mathrm{~b}$ & $14 \pm 1.37 \mathrm{c}$ & $5.03 \pm 0.09 \mathrm{~b}$ \\
\hline & & $\mathrm{Lp}$ & $19.23 \pm 2.53 \mathrm{c}$ & $13.19 \pm 0.72 \mathrm{c}$ & $71 \pm 5.15 \mathrm{a}$ & $7.97 \pm 1.23 \mathrm{a}$ \\
\hline & & Bv mix & $39.75 \pm 10.56 \mathrm{a}$ & $26.47 \pm 5.93 \mathrm{a}$ & $23 \pm 6.33 \mathrm{c}$ & $5.68 \pm 1.00 \mathrm{~b}$ \\
\hline & & Lp mix & $21.58 \pm 0.59 \mathrm{c}$ & $15.72 \pm 2.22 \mathrm{~b}$ & $46 \pm 9.47 \mathrm{~b}$ & $4.03 \pm 0.99 \mathrm{c}$ \\
\hline & \multirow[t]{5}{*}{ Very-dry PAW } & $\mathrm{Bv}$ & $19.47 \pm 5.46 \mathrm{c}$ & $8.23 \pm 2.83 \mathrm{~d}$ & $13 \pm 0.25 \mathrm{c}$ & $4.6 \pm 0.10 \mathrm{c}$ \\
\hline & & Lp & $16.05 \pm 2.74 \mathrm{~d}$ & $8.82 \pm 2.66 \mathrm{~d}$ & $60 \pm 2.92 \mathrm{a}$ & $6.35 \pm 0.40 \mathrm{ab}$ \\
\hline & & Bv mix & $26.02 \pm 5.37 \mathrm{~b}$ & $14.41 \pm 1.57 \mathrm{~b}$ & $14 \pm 1.64 \mathrm{c}$ & $3.89 \pm 1.17 \mathrm{~cd}$ \\
\hline & & Lp mix & $18.64 \pm 1.44 \mathrm{c}$ & $12.82 \pm 0.99 \mathrm{c}$ & $64 \pm 0.91 \mathrm{a}$ & $5.54 \pm 0.82 \mathrm{~b}$ \\
\hline & & sig & $* * *$ & $* * *$ & $* * *$ & $* * *$ \\
\hline
\end{tabular}

Values on the same column followed by different letters present significant differences. LSD, least significant difference. $* * * \mathrm{P} \leq 0.001$.

The water potential of the tillers measured at 5:00 am and 12:30 pm of $\mathrm{Lp}$ and Bv presented a three-way interaction $(\mathrm{P} \leq 0.05)$ between the soil physical condition, water treatment and species (Table 2). The species presented differences in the water potential under the same soil structure and soil water restriction. The tillers of $\mathrm{Bv}$ and $\mathrm{Lp}$ grown under DS and very-dry PAW presented the highest negative tiller water potential, at 5:00 am and 12:30 pm, such that values for
$\mathrm{Bv}$ were -2.66 MPa and -3.22 $\mathrm{MPa}$, respectively, and $-2.19 \mathrm{MPa},-3.51 \mathrm{MPa}$ for Lp, respectively $(\mathrm{P} \leq 0.001)$. The less negative tiller water potentials, ranging between -1.03 MPa and -1.60 MPa, were measured in the tillers of the species that grew under US and optimum PAW ( $\mathrm{P} \leq 0.001$; Table 2$)$. The tiller dry matter of the species $\mathrm{Bv}$ and $\mathrm{Lp}$ after the water potential evaluation was higher in $\mathrm{Bv}$ than $\mathrm{Lp}$ in both soil structure and soil water restriction $(\mathrm{P} \leq 0.001$; Table 2$)$. 
Table 2. Effect of two water treatments (optimum PAW and very-dry PAW) and three sward (Bromus valdivianus $(\mathrm{Bv})$, Lolium perenne (Lp) and mixed $\mathrm{Bv}+\mathrm{Lp}$ ) under a disturbed (DS) and undisturbed (US) soil condition, in the physiological (tiller water potential (TWP)) and tiller dry matter (TDM) response.

\begin{tabular}{|c|c|c|c|c|c|c|}
\hline & & & $\begin{array}{l}\text { TWP (MPa) } \\
\text { 5:00am }\end{array}$ & $\begin{array}{l}\text { TWP (MPa) } \\
12: 30 \mathrm{pm}\end{array}$ & $\begin{array}{l}\text { TDM (g DM) } \\
\text { 5:00am }\end{array}$ & $\begin{array}{l}\text { TDM (g DM) } \\
12: 30 \mathrm{pm}\end{array}$ \\
\hline Soil structure * & Soil water restriction* & Pastures & & & & \\
\hline \multirow[t]{8}{*}{ Disturbed } & Optimum PAW & $\mathrm{Bv}$ & $-1.26 \pm 0.04 b$ & $-1.81 \pm 0.08 \mathrm{~d}$ & $0.20 \pm 0.02 \mathrm{~d}$ & $0.20 \pm 0.02 \mathrm{~b}$ \\
\hline & & $\mathrm{Lp}$ & $-1.49 \pm 0.15 \mathrm{c}$ & $-1.83 \pm 0.09 \mathrm{~d}$ & $0.07 \pm 0.01 \mathrm{f}$ & $0.08 \pm 0.00 \mathrm{~d}$ \\
\hline & & Bv mix & $-1.08 \pm 0.06 \mathrm{ab}$ & $-1.71 \pm 0.16 \mathrm{c}$ & $0.20 \pm 0.03 \mathrm{~d}$ & $0.17 \pm 0.04 \mathrm{~b}$ \\
\hline & & Lp mix & $-1.37 \pm 0.19 b$ & $-2.06 \pm 0.08 \mathrm{e}$ & $0.06 \pm 0.01 \mathrm{f}$ & $0.10 \pm 0.00 \mathrm{~d}$ \\
\hline & Very-dry PAW & $\mathrm{Bv}$ & $-2.66 \pm 0.39 \mathrm{e}$ & $-3.22 \pm 0.09 \mathrm{~g}$ & $0.15 \pm 0.01 \mathrm{e}$ & $0.13 \pm 0.02 \mathrm{c}$ \\
\hline & & $\mathrm{Lp}$ & $-2.19 \pm 0.08 \mathrm{e}$ & $-3.51 \pm 0.32 \mathrm{~g}$ & $0.07 \pm 0.01 \mathrm{f}$ & $0.07 \pm 0.01 \mathrm{~d}$ \\
\hline & & Bv mix & $-2.02 \pm 0.24 \mathrm{e}$ & $-2.82 \pm 0.18 \mathrm{f}$ & $0.22 \pm 0.06 \mathrm{c}$ & $0.13 \pm 0.02 \mathrm{c}$ \\
\hline & & Lp mix & $-2.25 \pm 0.24 \mathrm{e}$ & $-3.04 \pm 0.46 \mathrm{~g}$ & $0.06 \pm 0.01 \mathrm{f}$ & $0.07 \pm 0.01 \mathrm{~d}$ \\
\hline \multirow[t]{8}{*}{ Undisturbed } & Optimum PAW & $\mathrm{Bv}$ & $-1.03 \pm 0.04 \mathrm{a}$ & $-1.48 \pm 0.09 \mathrm{a}$ & $0.37 \pm 0.03 \mathrm{a}$ & $0.24 \pm 0.03 \mathrm{a}$ \\
\hline & & Lp & $-1.60 \pm 0.24 \mathrm{c}$ & $-1.57 \pm 0.13 b$ & $0.12 \pm 0.02 \mathrm{e}$ & $0.11 \pm 0.02 \mathrm{~cd}$ \\
\hline & & Bv mix & $-1.09 \pm 0.11 \mathrm{ab}$ & $-1.60 \pm 0.16 b$ & $0.31 \pm 0.02 \mathrm{~b}$ & $0.25 \pm 0.05 \mathrm{a}$ \\
\hline & & Lp mix & $-1.04 \pm 0.07 \mathrm{a}$ & $-1.33 \pm 0.03 \mathrm{a}$ & $0.12 \pm 0.03 \mathrm{e}$ & $0.11 \pm 0.03 \mathrm{~cd}$ \\
\hline & Very-dry PAW & $\mathrm{Bv}$ & $-1.78 \pm 0.07 \mathrm{~d}$ & $-2.36 \pm 0.24 \mathrm{f}$ & $0.23 \pm 0.03 \mathrm{c}$ & $0.24 \pm 0.05 \mathrm{a}$ \\
\hline & & $\mathrm{Lp}$ & $-1.38 \pm 0.18 b$ & $-2.11 \pm 0.18 \mathrm{e}$ & $0.15 \pm 0.04 \mathrm{e}$ & $0.12 \pm 0.02 \mathrm{c}$ \\
\hline & & Bv mix & $-1.61 \pm 0.07 \mathrm{c}$ & $-2.15 \pm 0.25 \mathrm{e}$ & $0.34 \pm 0.03 \mathrm{a}$ & $0.25 \pm 0.07 \mathrm{a}$ \\
\hline & & $\begin{array}{l}\text { Lp mix } \\
\text { sig }\end{array}$ & $\begin{array}{l}-1.63 \pm 0.26 \mathrm{c} \\
* * *\end{array}$ & $\begin{array}{l}-2.13 \pm 0.16 \mathrm{e} \\
* * *\end{array}$ & $\begin{array}{l}0.11 \pm 0.01 \mathrm{e} \\
* * *\end{array}$ & $\begin{array}{l}0.10 \pm 0.03 \mathrm{~cd} \\
* * *\end{array}$ \\
\hline
\end{tabular}

Values on the same column followed by different letters present significant differences. LSD, least significant difference. $* * * \mathrm{P} \leq 0.001$.

Individual tillers of $\mathrm{Bv}$ and $\mathrm{Lp}$ grown as monoculture or as mixed pasture (Table 3 ) had a threeway interaction for total lamina length (TLL; $\mathrm{P} \leq$ $0.001)$, leaf area (LA; $\mathrm{P} \leq 0.001)$, total tiller mass (TTM; P $\leq 0.001)$ and number of live leaves (NLL; $P \leq 0.01)$, while sheath length was statistically similar for all the treatments $(p>0.05)$. Bromus valdivianus as monoculture under optimum PAW in US had the greater TLL, LA, and NLL values.
These results for TLL, LA, and NLL were 1.5, 1.5 and 1.2 times larger than those of $\mathrm{Bv}$ in the mixed pasture $(\mathrm{Bv}+\mathrm{Lp})$. Also, TLL for $\mathrm{Bv}$ growing in US was 2.6 times greater under Bv in DS under optimum PAW. All Bv and Lp values of TLL, LA, and NLL diminished when the soil water restriction increased to very-dry PAW, regardless of whether the species were growing as monoculture or as a mixed pasture (Table 3). 
Table 3. Response of individual tillers of Bromus valdivianus (Bv) and Lolium perenne (Lp) grown alone and mixed under the two water treatments (optimum PAW and very-dry PAW) in disturbed (DS) and undisturbed (US) soil conditions.

\begin{tabular}{|c|c|c|c|c|c|c|c|}
\hline & & & $\begin{array}{l}\text { Total lamina length } \\
(\mathrm{mm})\end{array}$ & $\begin{array}{l}\text { Sheath lenght } \\
(\mathrm{mm})\end{array}$ & $\begin{array}{l}\text { Leaf area } \\
\left(\mathrm{cm}^{2}\right)\end{array}$ & $\begin{array}{l}\text { Total tiller mass } \\
(\mathrm{g} \text { DM) }\end{array}$ & $\begin{array}{l}\text { Number of live } \\
\text { leaves }\end{array}$ \\
\hline Soil structure * & $\begin{array}{l}\text { Soil water } \\
\text { restriction * }\end{array}$ & Pastures & & & & & \\
\hline \multirow[t]{8}{*}{ Disturbed } & \multirow[t]{4}{*}{ Optimum PAW } & $\mathrm{Bv}$ & $54.04 \pm 7.97 \mathrm{~d}$ & $3.91 \pm 0.31$ & $11.60 \pm 1.36 \mathrm{e}$ & $0.10 \pm 0.02 \mathrm{c}$ & $3.17 \pm 0.33 \mathrm{~d}$ \\
\hline & & Lp & $25.71 \pm 6.85 \mathrm{e}$ & $4.08 \pm 0.26$ & $3.67 \pm 1.06 \mathrm{f}$ & $0.05 \pm 0.01 \mathrm{~d}$ & $2.50 \pm 0.25 \mathrm{e}$ \\
\hline & & Bv mix & $55.10 \pm 10.63 \mathrm{~d}$ & $3.28 \pm 0.78$ & $14.23 \pm 2.99 \mathrm{~d}$ & $0.17 \pm 0.04 \mathrm{c}$ & $3.83 \pm 0.73 \mathrm{c}$ \\
\hline & & Lp mix & $34.23 \pm 2.86 \mathrm{e}$ & $4.75 \pm 0.38$ & $4.86 \pm 0.47 \mathrm{e}$ & $0.07 \pm 0.01 \mathrm{~d}$ & $2.67 \pm 0.44 \mathrm{e}$ \\
\hline & \multirow[t]{4}{*}{ Very-dry PAW } & $\mathrm{Bv}$ & $30.24 \pm 6.19 \mathrm{e}$ & $4.52 \pm 0.56$ & $6.12 \pm 1.29 \mathrm{e}$ & $0.07 \pm 0.02 \mathrm{~d}$ & $1.83 \pm 0.22 \mathrm{f}$ \\
\hline & & $\mathrm{Lp}$ & $21.48 \pm 3.41 \mathrm{e}$ & $4.50 \pm 0.54$ & $4.94 \pm 1.17 \mathrm{e}$ & $0.06 \pm 0.01 \mathrm{~d}$ & $2.18 \pm 0.08 \mathrm{f}$ \\
\hline & & Bv mix & $37.75 \pm 4.85 \mathrm{e}$ & $3.08 \pm 0.85$ & $6.24 \pm 1.22 \mathrm{e}$ & $0.07 \pm 0.02 \mathrm{~d}$ & $2.17 \pm 0.17 \mathrm{f}$ \\
\hline & & Lp mix & $22.27 \pm 3.98 \mathrm{e}$ & $4.52 \pm 0.25$ & $3.37 \pm 0.26 \mathrm{f}$ & $0.06 \pm 0.01 \mathrm{~d}$ & $2.17 \pm 0.33 \mathrm{f}$ \\
\hline \multirow[t]{9}{*}{ Undisturbed } & \multirow[t]{4}{*}{ Optimum PAW } & $\mathrm{Bv}$ & $142.79 \pm 31.68 \mathrm{a}$ & $6.52 \pm 0.94$ & $38.86 \pm 9.33 \mathrm{a}$ & $0.34 \pm 0.06 \mathrm{a}$ & $4.75 \pm 0.29 \mathrm{a}$ \\
\hline & & $\mathrm{Lp}$ & $48.69 \pm 9.95 \mathrm{~d}$ & $4.75 \pm 0.32$ & $9.93 \pm 2.64 \mathrm{e}$ & $0.12 \pm 0.03 \mathrm{c}$ & $3.17 \pm 0.30 \mathrm{~d}$ \\
\hline & & Bv mix & $93.70 \pm 30.86 b$ & $5.33 \pm 0.65$ & $25.90 \pm 10.64 b$ & $0.29 \pm 0.10 \mathrm{a}$ & $4.00 \pm 1.04 b$ \\
\hline & & Lp mix & $45.53 \pm 8.31 \mathrm{~d}$ & $5.58 \pm 0.73$ & $7.97 \pm 0.47 \mathrm{e}$ & $0.10 \pm 0.01 \mathrm{c}$ & $2.67 \pm 0.33 \mathrm{e}$ \\
\hline & \multirow[t]{5}{*}{ Very-dry PAW } & $\mathrm{Bv}$ & $84.73 \pm 13.83 \mathrm{c}$ & $5.19 \pm 0.83$ & $16.79 \pm 4.44 \mathrm{c}$ & $0.22 \pm 0.09 \mathrm{~b}$ & $3.83 \pm 0.30 \mathrm{c}$ \\
\hline & & $\mathrm{Lp}$ & $53.68 \pm 12.73 \mathrm{~d}$ & $4.81 \pm 0.42$ & $6.52 \pm 0.42 \mathrm{e}$ & $0.11 \pm 0.02 \mathrm{c}$ & $3.58 \pm 0.55 \mathrm{c}$ \\
\hline & & Bv mix & $84.63 \pm 25.75 \mathrm{c}$ & $5.33 \pm 0.55$ & $16.84 \pm 8.37 \mathrm{c}$ & $0.21 \pm 0.08 \mathrm{~b}$ & $3.50 \pm 0.76 \mathrm{c}$ \\
\hline & & Lp mix & $44.18 \pm 11.40 \mathrm{~d}$ & $4.95 \pm 0.58$ & $5.98 \pm 1.05 \mathrm{e}$ & $0.11 \pm 0.01 \mathrm{c}$ & $2.83 \pm 0.44 \mathrm{e}$ \\
\hline & & Sig & $* * *$ & ns & $* * *$ & $* * *$ & $* *$ \\
\hline
\end{tabular}

Values on the same column followed by different letters present significant differences. LSD, least significant difference. ***P $\leq 0.001 ; * * \mathrm{P} \leq 0.01 ; * \mathrm{P} \leq 0.05 ;$ ns $\mathrm{P}>0.05$, ns: no significant difference.

The shoot and root mass production of $\mathrm{Lp}$ and $\mathrm{Bv}$ grown as monoculture and as mixed pasture presented differences between species, soil structure and soil water restriction ( $\mathrm{P} \leq 0.05$; Figure 3$)$. Shoot mass production of $\mathrm{Bv}, \mathrm{Lp}$ and $\mathrm{Bv}+\mathrm{Lp}$ pastures in US under optimum PAW treatment was greater by $1.9,2.6$ and 1.7 times, respectively, than the one in DS under optimum PAW ( $\mathrm{P} \leq 0.05)$. Root mass was greater in DS under very-dry PAW compared to that of US under optimum PAW (P $\leq 0.05)$. Lolium perenne growing under US had greater shoot mass production $(\mathrm{P} \leq 0.05)$ compared to DS $\mathrm{x}$ Lp, DS $\mathrm{x}$
$\mathrm{Bv}$ and $\mathrm{DS} \times \mathrm{Bv}+\mathrm{Lp}$ pasture. On the other hand, Bv growing under DS and US presented similar root mass production to $\mathrm{DS} \times \mathrm{Bv}+\mathrm{Lp}$ pasture $(\mathrm{P} \leq 0.05)$, but was higher than Lp in the DS and US. In the DS $x$ very-dry PAW the root mass production in the $0-10$, 10-20, 20-35 and 35-50 cm soil depth was higher than in US $(\mathrm{P} \leq 0.05)$. Lolium perenne had more root mass between $0-10 \mathrm{~cm}$ soil depth than $\mathrm{Bv}$ and $\mathrm{Bv}+\mathrm{Lp}$ pasture, while $\mathrm{Bv}$ had more root mass than $\mathrm{Lp}$ and $\mathrm{Bv}+\mathrm{Lp}$ pasture in $10-20 \mathrm{~cm}, 20-35 \mathrm{~cm}$ and $35-50 \mathrm{~cm}$ soil depth in US and DS and under both soil water restriction $(\mathrm{P} \leq 0.05)$. 

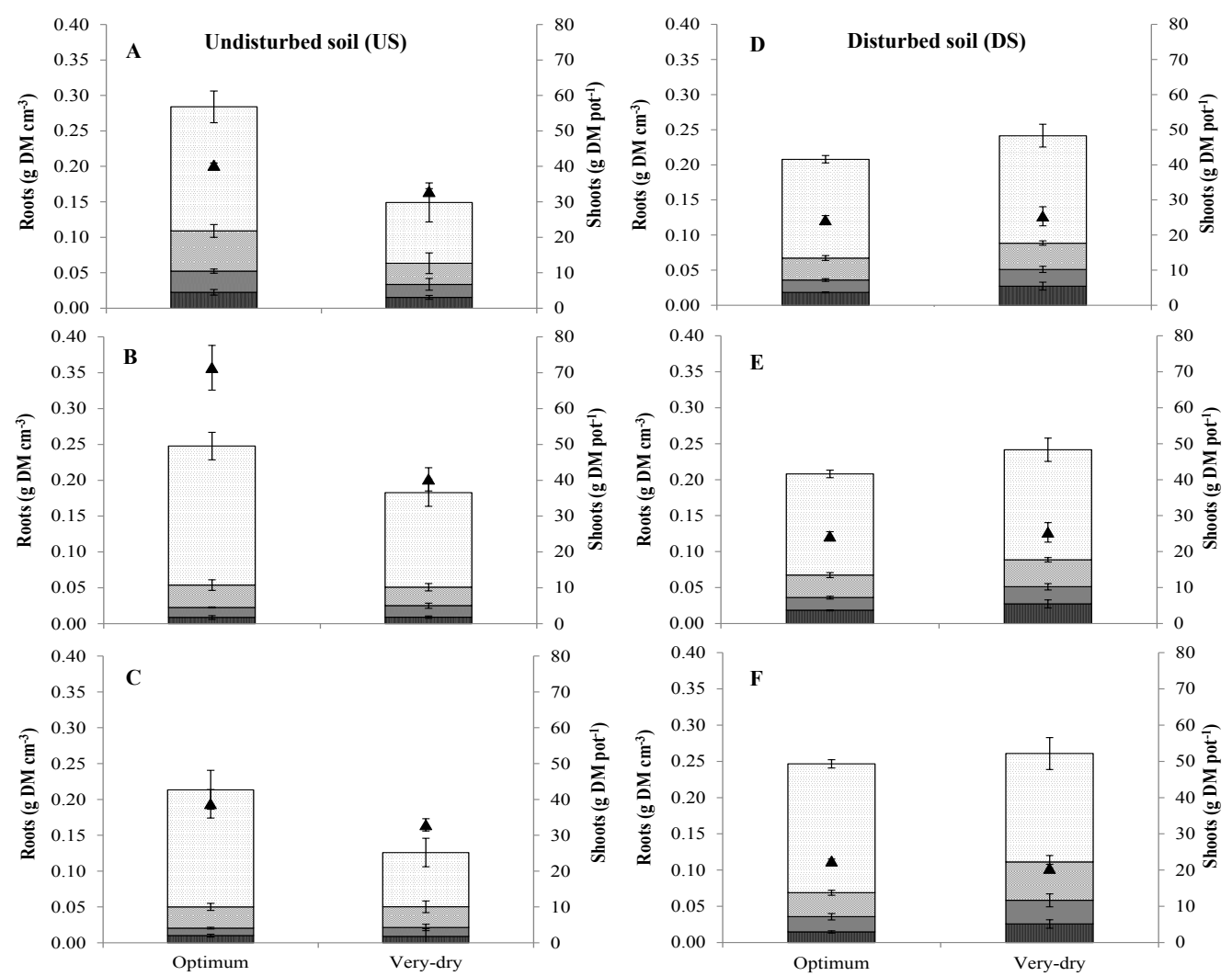

Figure 3. Shoot mass (g DM pot $\left.{ }^{-1} \mathbf{\Delta}\right)$ and root mass production $\left(\mathrm{g} \mathrm{DM} \mathrm{cm}^{-3}\right)$ of Bromus valdivianus and Lolium perenne in different soil depths ( $): 0-10 ; \square: 10-20 ; \square: 20-35 ; \quad \square: 35-50 \mathrm{~cm}$ ) under two soil water restrictions (optimum PAW and very-dry PAW) (P $\leq 0.05)$ A) Bromus valdivianus (Bv) in undisturbed soil (US); B) Lolium perenne (Lp) in US; C) Bv+Lp mixed in US. D) Bromus valdivianus (Bv) in disturbed soil (DS); E) Lolium perenne (Lp) in DS; F) Bv+Lp mixed in DS. Average values are presented and vertical bars indicate standard error of the mean $(n=3)$.

Finally, in order to describe the interaction between species, the competitive ability of the species was expressed according to the relative competitive index (RCI; Figure 4). For shoot mass and tiller number, Lp had the greater RCI in US under optimum PAW $(\mathrm{P} \leq$ 0.05) (Figure 4A and B), which means that Lp shoot mass and tiller number in the mixed pasture were negatively affected compared to Lp growing as a mono culture pasture. Bv presented larger RCI in DS under optimum PAW ( $\leq 0.05$; Figure $4 C)$. In US, Lp shoot mass production was negatively affected by competition with $\mathrm{Bv}$ under very-dry $\mathrm{PAW}(\mathrm{P} \leq 0.05$; Figure 4A). Tiller number of the species under verydry PAW was not negatively affected by the competition ( $\mathrm{P}>0.05$; Figure 4). 

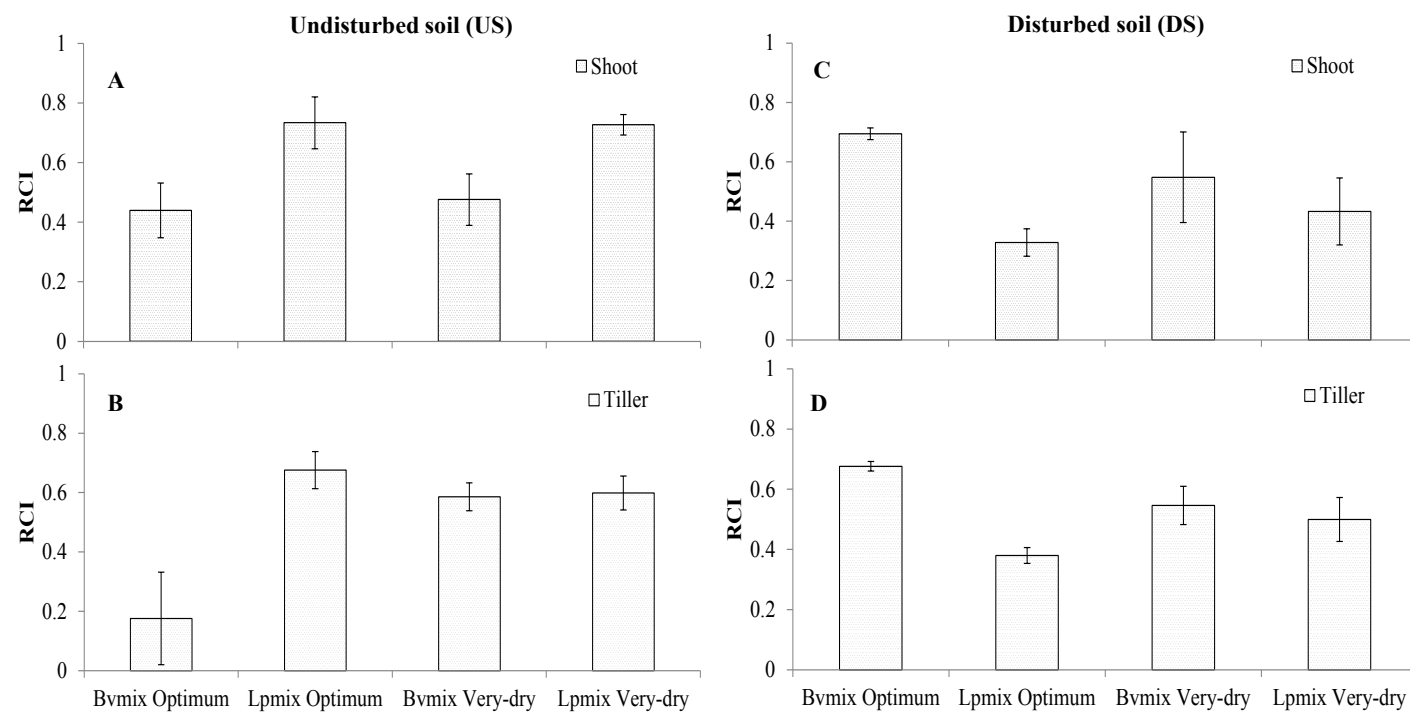

Figure 4. Relative Competitive Index (RCI) of Bromus valdivianus (Bv) mixed with Lolium perenne (Lp). A) RCI of shoot dry matter in undisturbed soil (US). B) RCI of tiller number in US. C) RCI of shoot dry matter in disturbed soil (DS). D) RCI of tiller number in DS. Bvmix optimum PAW (Bv mixed with Lp, under optimum PAW), Lpmix optimum PAW (Lp mixed with Bv under optimum PAW), Bvmix very-dry PAW (B Bv mixed with Lp, under very-dry PAW), Lpmix very-dry PAW (Lp mixed with Bv under very-dry PAW). Average values are presented and vertical bars indicate standard error of the mean $(n=3)$.

\subsection{Changes in soil physical properties under differ- ent plant species and water managements}

The physical properties of the soil were measured before sowing (Figure $5 \mathrm{~A}, \mathrm{C}, \mathrm{E}$ ) and at the end of the study when the plants were cut and harvested (Figure 5 B, D, F). Before sowing, soil bulk density did not differ between the utilized pots reaching values between $0.72 \mathrm{~g} \mathrm{~cm}^{-3}$ and $0.80 \mathrm{~g} \mathrm{~cm}^{-3}$. Regarding the volume of macropores $(\varnothing>50 \mu \mathrm{m})$, which are registered by the air capacity $(\mathrm{AC})$ of the soil, the utilized pots did not show statistical differences $(P>0.05)$. The same happened for the PAW reaching values of volumetric water content between $26 \%$ and $30 \%$. 


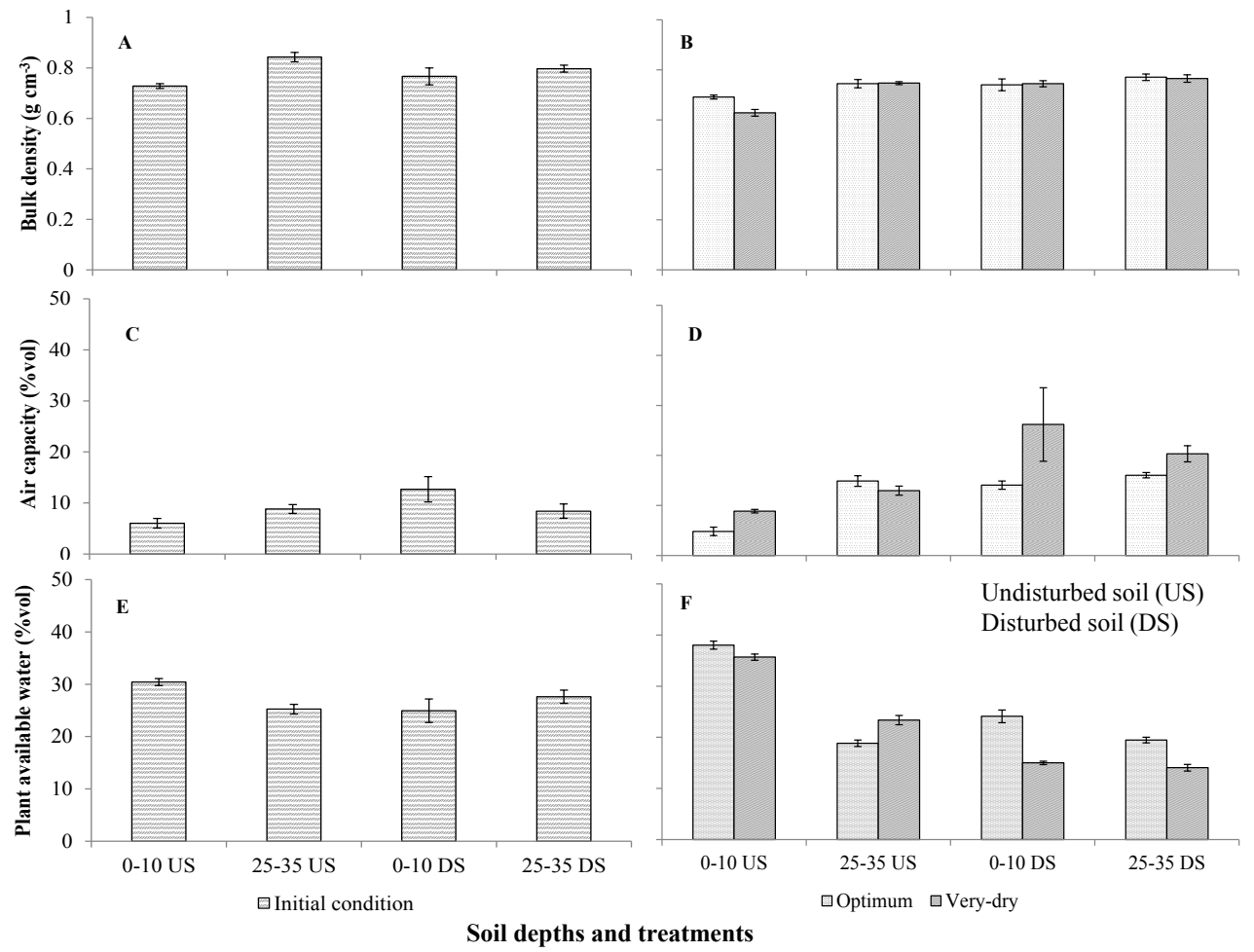

Figure 5. Soil physical properties at $0-10 \mathrm{~cm}$ and 25-35 of depth in US (undisturbed soil) and DS (disturbed soil) before sowing, A) Bulk density $\left(\mathrm{g} \mathrm{cm}^{-3}\right)$, C) Air capacity (AC) (\% vol) and E) Plant available water (PAW) (\% vol). Soil physical properties at $0-10 \mathrm{~cm}$ and $25-35 \mathrm{~cm}$ of depth in US and DS for optimum PAW and very-dry PAW at the end of the experiment (after 1196 accumulated degree day (ADD)), B) Bulk density ( $\mathrm{g} \mathrm{cm}^{-3}$ ), D) Air capacity (AC) (\% vol) and F) Plant available water (PAW) (\% vol). Average values are presented and vertical bars indicate standard error of the mean $(n=3)$.

At the end of the experiment (1196 ADD) differences in the soil physical properties were observed (Figure 5). The bulk density of the soil reached values between $0.62 \mathrm{~g} \mathrm{~cm}^{-3}$ and $0.77 \mathrm{~g} \mathrm{~cm}^{-3}$. In US, bulk density increased with soil depth, whereas remains constant in DS (following similar tendencies observed before the experiment; Figure $5 \mathrm{~A}$ and $\mathrm{B}$ ). The air capacity (AC) at $0-10 \mathrm{~cm}$ of soil depth in DS increased being more evident in the very-dry PAW water treatment, where the DS treatment presented the higher $\mathrm{AC}(\mathrm{P} \leq 0.05)$.
On the other hand, the plant available water (PAW; Figure $5 \mathrm{~F}$ ) was greater between $0-10 \mathrm{~cm}$ soil depth in US compared to the other treatments. In general, a decrease in PAW with increasing soil water restriction (very-dry PAW) was recorded $(\mathrm{P} \leq 0.05)$. The most evident changes were observed for the initially undisturbed soil. The only exception to this general tendency was observed for $25-35 \mathrm{~cm}$ in the US, which also presented a decrease in AC.

The air permeability (Ka) measured at 60 and $330 \mathrm{hPa}$ presented differences between optimum PAW and 
very-dry PAW (Figure 6 A). While these changes were non-statistically significant for US, for DS an increase in Ka was observed, so a greater Ka was measured in DS compared to that in US. In these terms Ka values for the DS ranged between 58 and $224 \mu \mathrm{m}^{2}$, whereas for the US they fluctuated between 29 and $119 \mu \mathrm{m}^{2}$. Finally, in order to describe the changes in the continuity of the macropores (considering 60 and $330 \mathrm{hPa}$ treatments, the $\mathrm{C}_{2}$ and $\mathrm{C}_{3}$ indexes were calculated. The $\mathrm{C}_{2}$ index presented similar results as those observed for $\mathrm{Ka}$. On the other hand, $\mathrm{C}_{3}$ index presented some differences to the previously observed tendencies in $\mathrm{Ka}$ and $\mathrm{C}_{2} . \mathrm{C}_{3}$ was greater in optimum PAW and verydry PAW at $60 \mathrm{hPa}$ at $0-10 \mathrm{~cm}$ of soil depth in the US, being followed by DS $25-35 \mathrm{~cm}$ soil depth and 0-10 $\mathrm{cm}$ in DS (Figure $6 \mathrm{~B}$ and $\mathrm{C} ; \mathrm{P} \leq 0.05$ ).

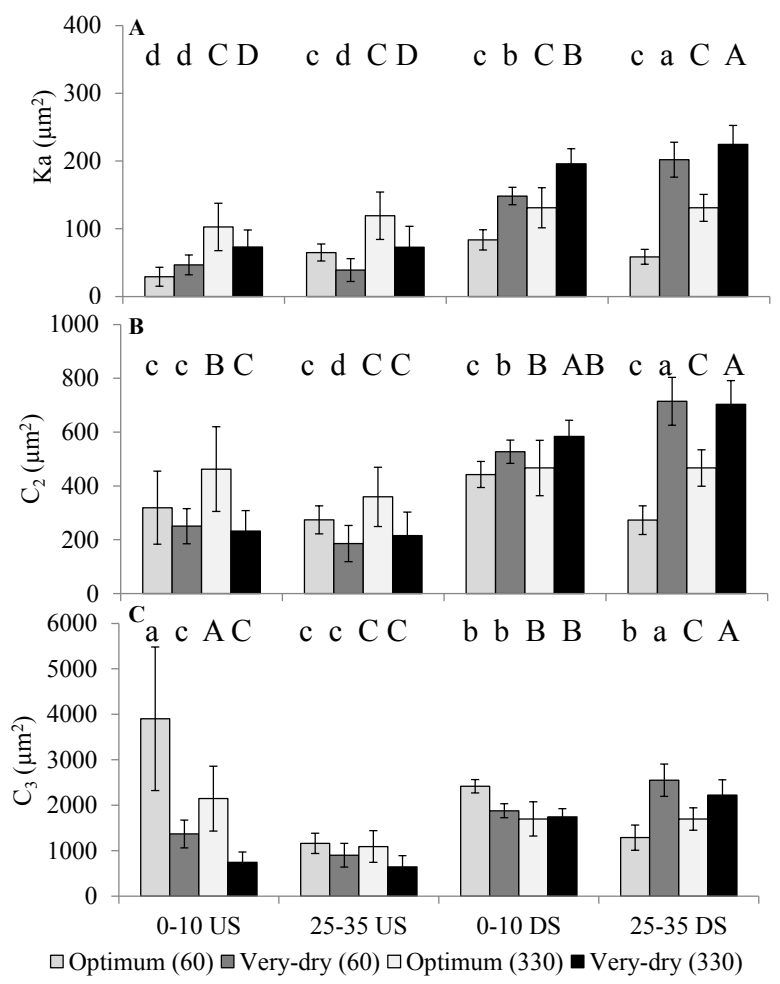

Figure 6. Air permeability (Ka) (A) and the pore continuity index $\left(\mathrm{C}_{2}(\mathrm{~B})\right.$ and $\left.\mathrm{C}_{3}(\mathrm{C})\right)$ measured at water tensions of 60 and $330 \mathrm{hPa}$ from samples collected at $0-10 \mathrm{~cm}$ and $25-35 \mathrm{~cm}$ of depth in undisturbed (US) and disturbed (DS) soil for optimum PAW and very-dry PAW water treatment at the end of the experiment (after 1196 accumulated degree day (ADD)). Average values are presented and vertical bars indicate standard error of the mean $(\mathrm{n}=3)$. Different lower-case letters indicate a significant difference between depth*soil at $60 \mathrm{hPa}$. Different uppercase letters denote a significant difference between the depth*soil at $330 \mathrm{hPa}$. 


\section{Discussion}

In the South of Chile dairy and beef production are mainly based on pasture production and quality, where $\mathrm{Lp}$ and $\mathrm{Bv}$ are two important species due to their high production levels (12000 kg DM ha ${ }^{-1}$ year $^{-1}$; Balocchi and Teuber, 2003). However, while the growth of Lp under dry conditions is suppressed (Nie and Norton, 2009), Bv has been shown to be tolerant to soil water deficit (Stewart, 1996). The elongation of the leaves and the dry matter production of foliage and roots were higher for both species in US compared to those in DS (Table 1). This could be attributed to the cumulative greater PAW (considering both depths) at the end of the experiment in US compared to that in DS for each soil water restriction level (optimum PAW and very-dry PAW). The US showed greater PAW than DS between $0-10 \mathrm{~cm}$ soil depths. On the other hand, the pore continuity indexes defined at the macropore level (Figure 6) give an idea of the pore network that roots can use to access water. High levels of $\mathrm{C}_{2}$ and $\mathrm{C}_{3}$ indexes in all the soils depths in US and in DS (Figure 6) support these findings. Zúniga et al. (2015) found that both pore continuity indexes $\left(\mathrm{C}_{2}\right.$ and $\left.\mathrm{C}_{3}\right)$ were higher in a naturalized pasture (no tilled) with fertilization $\left(\mathrm{C}_{2}\right.$ showed 350 $\mu \mathrm{m}^{2}$ ), which presented a better evolution in the pore continuity than the other pastures where the soil structures were mechanically affected by conventional tillage. According to this, we expected the US to present higher values of both $\mathrm{C}_{2}$ and $\mathrm{C}_{3}$ than DS. However, this was only observed in $C_{3}$ (Figure 6), which is more sensitive to changes in pore continuity than $\mathrm{C}_{2}$ (Groenevelt et al., 1984). At the same time, when comparing the porosity of the soils before and after the conducted experiment, the disturbed soil presented an increase in air capacity (AC), which is related to the formation of cracks (macropores available to the convective transport of air) due to the well-known shrinkage behavior of volcanic ash soils (Dörner et al., 2010).
The average daily leaf elongation and the accumulated leaf elongation were higher in Bv than in Lp. This is supported by the number of leaves that $\mathrm{Bv}$ can grow at the same time and also the number of live leaves that $\mathrm{Bv}$ presented in a single tiller, e.g. while $\mathrm{Lp}$ had three live leaves per tiller, Bv had four live leaves per tiller, which explains the higher accumulated leaf elongation of $\mathrm{Bv}$ compared to Lp (Table 3). A similar response has been reported by López et al. (2013) regarding the accumulated leaf elongation and leaf length of $\mathrm{Bv}$ under soil water restriction.

The leaf elongation and senescence rates per day were higher in $\mathrm{Bv}$ under US, with the elongation of $\mathrm{Bv}$ almost double that of $\mathrm{Lp}$ under the same soil structure, and 4 times larger than in DS. The leaf elongation is associated to the growth strategy of pasture species (Chaves et al., 2002), thus under drought conditions the species decreased their leaf elongation in order to protect the plant development and survival during the year (Volaire et al., 2009), and to take water from the soil, which depends on the root mass and depth (Sandral et al., 2006). A developed soil structure is a relevant factor to face the use of water by plants, because an aggregated soil with a stable soil structure (e.g. US) has a continuous pore system, which provides water for plants despite being under different levels of water restriction (Dörner et al., 2013). In these terms, when comparing the changes in AC, PAW and Ka between both soils and water management strategies (Figures 5 and 6), the greatest changes were observed in DS compared to US. This highlights that compared to US, the disturbed soil is unstable, since the soil shrinkage induced by the hydraulic stresses (see volumetric water contents of the very-dry PAW in Figure 1) and root development (Figure 3), increased the $\mathrm{AC}$ and $\mathrm{Ka}$ by losing PAW (Figures 5 and 6). This soil structure evolution in the medium term will favor the formation of a stable and continuous pore system (as discussed by Zúniga et al., 2015 in a field experiment), which is 
relevant, since it facilitates the vertical flow of water through the soil profile and allows for better retention, availability and distribution of water in the soil to be used by plants (Acevedo and Silva, 2003).

The population density of tillers was different between the species, being Lp the species that presented the highest tiller density per pot. One positive attribute of $\mathrm{Lp}$ is its tillering ability under optimal environmental conditions and it is one of the species with the highest tiller density reported (Hernández-Garay et al., 1997, Bahmani et al., 2003). When reaching 1196 ADD Lp presented a high shoot mass production in US, which was supported by the high Lp tiller population; differences were expressed as a larger tiller population per pot (extra 100 tillers per pot in US compared to those in DS) and the shoot mass was double that in DS (Hernández-Garay et al., 1997, Bahmani et al., 2003). However, Lp was negatively affected by soil structure and soil water restriction (DS x very-dry PAW). On the other hand, $\mathrm{Bv}$ presented similar tiller density under both soil structures and soil water restriction, showing that the rate of tillering of $\mathrm{Bv}$ was not significantly affected when the environmental conditions changed according to the restrictions applied in the study. Under these conditions $\mathrm{Bv}$, as a part of a pasture, should provide a more stable plant population during the year, which would prevent the entry of opportunistic species of low performance and poor nutritional quality. A similar situation has been reported to occur in the field (Descalzi et al., 2011), where Bv maintained a stable rate of tiller appearance and death during the year compared to Lp, which showed large variations in the tiller density, according to the climatic fluctuations throughout the year.

Considering the interactions that interfered with root production (soil structure $\mathrm{x}$ soil water restriction $\mathrm{x}$ pasture), a higher root development was measured in very-dry PAW for DS, while in US higher root production was under optimum PAW for Bv, $\mathrm{Lp}$ and $\mathrm{Bv}+\mathrm{Lp}$ pasture. Bromus valdivianus presented differences for root growth between the soil structure and the soil water restriction, since $\mathrm{Lp}$ and $\mathrm{Bv}+\mathrm{Lp}$ pasture did not differ in the root production between the soil water restrictions under DS (Figure 3). It is well known that a developed root system allows further exploration of soil profile (Volaire and Gandoin, 1996), such as that of Bromus sp. which develops a deeper root system compared to other species, e.g. root depth of B. stamineus varied between $0.82 \mathrm{~m}-1.46 \mathrm{~m}$ in different soils in Australia, compared to Lp which presented roots between $0.76 \mathrm{~m}-1.05 \mathrm{~m}$ of soil depth (Nie et al., 2008). Bromus valdivianus has a moderately deep root system, approximately one meter, which goes deeper than Lp (Stewart, 1996). Under optimum PAW conditions and a continuous pore system, as in US, there was a higher root mass, which also contributed to the increase in foliage mass production compared to that of DS. Root mass was higher in the first $10 \mathrm{~cm}$ of soil depth, and under very-dry PAW it had more root mass at this soil depth than in optimum PAW (Figure 3). In another study, Dactilys glomerata (Dg) under water restriction had less root mass in the first $20 \mathrm{~cm}$ of soil depth than the Dg control with irrigation, but it was still one of the species with a higher root mass and maximum rooting depth under moderate soil water restriction compared to other species, such as Poa pratensis and Poa trivialis (Zwicke et al., 2015).

The evaluation of the plants' water potential indicated that tiller water potential was more negative in DS and reached lower values in very-dry PAW (Table 2), for example under a high soil water restriction, that meant that they were close to wilting point for DS. Plants had less water content in DS than the plants at the same level of soil water restriction in US, which correlates to the higher plant available water in US (Figure 5). Both species $\mathrm{Bv}$ and $\mathrm{Lp}$ presented the most negative water potential in the very-dry PAW at 5:00 am and 12:30 pm compared to the optimum PAW under US and DS. 
In other studies, Bromus sp. presented water potentials more negative than those of Lp. Under irrigation, Bromus inermis presented a water potential of $-0.9 \mathrm{MPa}$ and Lp had -1.5 MPa, while under a severe drought, the water potential changed to -2.1 MPa for B. inermis and -1.9 MPa in Lp (Bahrani et al., 2010). For Dg and Festuca arundinacea $(\mathrm{Fa})$ water potential values of -2.6 MPa and -4.0 MPa, respectively, were reported under severe soil water restriction (Volaire and Lelièvre, 2001). Dactylis glomerata can survive greater soil water deficit, because it has an adaptation (summer dormancy) with a reduction of the leaf growth elongation and senescence rates (Volaire et al., 2009), while in another study both species Lp and $B$. inermis presented a greater negative water potential under drought conditions compared to irrigation (Okamoto et al., 2011).

The competition between both species $\mathrm{Bv}$ and Lp presented differential responses of shoot mass and tiller number under the different soil structure conditions and the two water treatments, highlighting the different strategies of the species under contrasting conditions (Chaves et al., 2002). When water was at optimum PAW, the competition negatively affected $\mathrm{Bv}$ in DS and Lp in US, because the plant available water was not the same between the soils in the $0-10 \mathrm{~cm}$ (US $=30 \%, \mathrm{DS}=23 \%$ ) and $25-35 \mathrm{~cm}$ (US $=19 \%$, DS $=18 \%$ ) soil depths. The species showed this effect in the relative competitive index. Under very-dry PAW the effect of the competition was similar for both species (Figure 4). In another study Bv was affected under competition with Lp growing under soil water restriction (López et al., 2013).

\section{Conclusion}

The growth response of Bromus valdivianus and Lolium perenne was affected by the different soil water restriction and soil structure conditions. The undisturbed soil presented more plant available water as well as improved pore continuity, which was better for root development and water accessibility by the growing species. Regarding the species responses under soil water restriction, while the shoot mass of Lp decreased more than that of Bv under very-dry PAW, Lp presented more tiller production and shoots per plant under optimum PAW, since Bv was not affected by the water condition for tiller production and shoot mass. Also Lp reduced the production when grown in mixture compared to when it was grown alone.

Finally, the undisturbed soil remained stable, whereas the homogenized soil presented a redistribution of soil porosity due to the soil shrinkage induced by the hydraulic stresses and root development in the very-dry treatment. The latter implied an increase in soil air capacity by losing pores to store water for plants. However, these hydraulic stresses allow for an increase in the continuity of pores, which will favor the water accessibility by plants in the medium and long-term.

\section{Acknowledgments}

The authors wish to thank FONDECYT grant 1130795 for funding and the PhD Scholarship CONICYT of the first author. They also acknowledge the logistic support of the Estación Experimental Agropecuaria Austral of Universidad Austral de Chile. Special thanks are given to Alejandro Werner and Iván Ordóñez.

\section{References}

Acevedo, E., Silva, P. 2003. Agronomía de la cero labranza. Vol. 10. Universidad de Chile, Departamento de Producción Agrícola. Universidad de Chile, Santiago, Chile. 
Bahmani, I., Thom, E.R., Matthew, C., Hooper, R.J., Lemaire, G. 2003. Tiller dynamics of perennial ryegrass cultivars derived from different New Zealand ecotypes: effects of cultivar, season, nitrogen fertiliser, and irrigation. Australian Journal of Agricultural Research. 54:803-817.

Bahrani, M.J., Bahrami, H., Haghighi, A.A.K. 2010. Effect of water stress on ten forage grasses native or introduced to Iran. Grassland Science. 56:1-5.

Balocchi, O., Caballero, J.M., Smith, R. 2001. Caracterización y variabilidad agronómica de 125 ecotipos de Bromus valdivianus Phil. recolectados en la provincia de Valdivia. Agro Sur. 29:64-77.

Balocchi, O., Teuber, N. 2003. Recursos forrajeros en producción de leche. Vol. 24. Seminario hagamos de la Lechería un mejor Negocio. Instituto de Investigaciones Agropecuarias INIA, Universidad Austral de Chile y Universidad de Chile. Serie Actas

Boisier, J.P., Rondanelli, R., Garreaud, R.D., Muñoz, F. 2016. Anthropogenic and natural contributions to the Southeast Pacific precipitation decline and recent megadrought in central Chile. Geophysical Research Letters. 43:413-421.

Chaves, M.M., Pereira, J.S., Maroco, J., Rodrigues, M.L., Ricardo, C.P.P., Osório, M.L., Carvalho, I., Faria, T., Pinheiro, C. 2002. How Plants Cope with Water Stress in the Field? Photosynthesis and Growth. Annals of Botany. 89:907-916.

Descalzi, C.A., López, I., Ordóñez, I., Castillo, D., Balocchi, O. 2011. Interacciones competitivas entre Bromus valdivianus Phil. y Lolium perenne L. en praderas pastoreadas por vacas lecheras de pesos contrastantes. Pages 205-206 in Proc. Libro de Resumenes del XXXVI Congreso Annual de la Sociedad Chilena de Produccion Animal, Instituto de Investigaciones Agropecuarias, Punta Arenas, Chile.
Dörner, J., Dec, D. 2007. La permeabilidad del aire y conductividad hidráulica saturada como herramienta para la caracterización funcional de los poros del suelo. Revista de la ciencia del suelo y nutrición vegetal. 7:1-13.

Dörner, J., Huertas, J., Cuevas, J.G, Leiva, C., Paulino, L., Arumí, J.L. 2015. Water content dynamics in a volcanic ash soil slope in southern Chile. Journal of Plant Nutrition and Soil Science. 178:693-702.

Dörner, J., Zúñiga, F., López, I. 2013. Short-term effects of different pasture improvement treatments on the physical quality of an andisol. Journal of soil science and plant nutrition. 13:381-399.

Dörner, J., Dec, D., Peng, X., Horn, R. 2010. Effect of land use change on the dynamic behaviour of structural properties of an Andisol in southern Chile under saturated and unsaturated hydraulic conditions. Geoderma. 159, 189-197.

Droogers, P., van der Meer, F.B.W, Bouma, J. 1997. Water accessibility to plant roots in different soil structures occurring in the same soil type. Plant and Soil. 188:83-91.

Grace, J.B. 1995. On the Measurement of Plant Competition Intensity. Ecology. 76:305-308.

Groenevelt, P.H., Kay, B.D., Grant, C.D. 1984. Physical assessment of a soil with respect to rooting potential. Geoderma. 34:101-114.

Hartge, K. Horn, R. 2009. Die physikalische Untersuchung von Böden. Praxis messmethoden Auswertung., Aufkage, Schweizarbart, Stuttgart.

Hernández-Garay, A., Matthew, C., Hodgson, J. 1997. Effect of spring grazing management on perennial ryegrass and ryegrass-white clover pastures. 2 . Tiller and growing point densities and population dynamics. New Zealand Journal of Agricultural Research. 40:37-50. 
Hodgson, J., Baker, R.D., Davies, A., Laidlaw, A.S, Leaver, J.D. 1981. Sward measurement handbook. British Grassland Society Hurley., Maidenhead.

López, I.F., Kemp, P.D., Dörner, J., Descalzi, C.A, Balocchi, O.A, García, S. 2013. Competitive Strategies and Growth of Neighbouring Bromus valdivianus Phil. and Lolium perenne L. Plants Under Water Restriction. Journal of Agronomy and Crop Science. 199:449-459.

Nie, Z., Norton, M.R. 2009. Stress Tolerance and Persistence of Perennial Grasses: The Role of the Summer Dormancy Trait in Temperate Australia Crop Science. 49:2405-2411.

Nie, Z.N., Miller, S., Moore, G.A., Hackney, B.F., Boschma, S.P., Reed, K.F.M., Mitchell, M., Albertsen, T.O., Clark, S., Craig, A.D, Kearney, G., Li, G.D., Dear, B.S. 2008. Field evaluation of perennial grasses and herbs in southern Australia. 2. Persistence, root characteristics and summer activity. Australian journal of experimental agriculture .48:424-435.

Okamoto, H., Ishii, K., An, P. 2011. Effects of soil moisture deficit and subsequent watering on the growth of four temperate grasses. Grassland Science. 57:192-197.

Ordóñez, I., López, I., Kemp, P., Descalzi, C.A., Horn, R., Zuñiga, F., Dec, D., Dörner, J. 2018. Effect of pasture improvement managements on physical properties and water content dynamics of a volcanic ash soil in southern Chile. Soil and Tillage Research. 178: 55-64.

Sandral, G.A., Dear, B.S., Virgona, J.M., Swan, A.D., Orchard, B.A. 2006. Changes in soil water content under annual- and perennial-based pasture systems in the wheatbelt of southern New South Wales. Australian Journal of Agricultural Research. 57:321-333.
Silsbury, J.H. 1961. A study of dormancy, survival and other characteristics in Lolium perenne $\mathrm{L}$. at Adelaide, S.A. Australian J. Agric. Res. 121-9.

Singh, D.K., Bird, P.R., Saul, G.R. 2003. Maximising the use of soil water by herbaceous species in the high rainfall zone of southern Australia: a review. Aust. J. Agric. Res. 54:677-691.

Stewart, A.V. 1996. Potential value of some Bromus species of the section Ceratochloa. New Zealand Journal of Agricultural Research. 39:611-618.

Teuber, N., Parga, J., Balocchi, O., Anwandter, V., Canesco, C., Abarzúa, A., Demanet, R., Lopetegui, J. 2007. Manejo del pastoreo. Consorcio Lechero, Osorno, Chile.

Volaire, F., Gandoin, J.M. 1996. The effect of age of the sward on the relationship between watersoluble carbohydrate accumulation and drought survival in two contrasted populations of cocksfoot (Dactylis glomerata L.). Grass and Forage Science. 51:190-198.

Volaire, F., Lelièvre F. 2001. Drought survival in Dactylis glomerata and Festuca arundinacea under similar rooting conditions in tubes. Plant Soil 229:225-234.

Volaire, F., Norton, M.R., Lelièvre, F. 2009. Summer Drought Survival Strategies and Sustainability of Perennial Temperate Forage Grasses in Mediterranean Areas. Crop Science. 49:2386-2392.

Zúñiga, F., Ivelic-Sáez, J., López, I., Huygens, D., Dörner, F.J. 2015. Temporal dynamics of the physical quality of an Andisol under a grazing system subjected to different pasture improvement strategies. Soil and Tillage Research. 145:233-241.

Zwicke, M., Picon-Cochard, C., Morvan-Bertrand, A., Prud'homme, M.-P., Volaire, F.. 2015. What functional strategies drive drought survival and recovery of perennial species from upland grassland? Annals of Botany. 116:1001-1015. 